\title{
Frekuensi Pemberian MP-ASI pada Baduta Stunting dan Non-Stunting Usia 6-24 Bulan Di Wilayah Kerja Puskesmas Sidotopo Kota Surabaya
}

\author{
Frequency of Complementary Feeding Practices in Stunting and Non- \\ Stunting Under Two Aged 6-24 Months in Sidotopo Health Center, Surabaya
}

\author{
Aisya Cici Putri Haryati*1, Trias Mahmudiono ${ }^{1}$
}

\begin{abstract}
ABSTRAK
Latar Belakang: Masalah gizi rentan terjadi pada anak berusia dibawah dua tahun yang diantaranya adalah stunting. Stunting merupakan masalah gizi kronis yang disebabkan oleh proses akumulatif dari rendahnya asupan gizi dan penyakit infeksi. Penyebab lain adalah kondisi social ekonomi yang dapat mempengarhui praktik pemberian MP-ASI. Kualitas gizi pada makanan dipengaruhi oleh keragaman pangan yang ditentukan oleh pendapatan keluarga, status pekerjaan, dan tingkat pendidikan.

Tujuan: Menganalisis hubungan praktik pemberian makan pendamping ASI dengan kejadian stunting dan nonstunting pada baduta usia 6-24 bulan di Kelurahan Sidotopo, Kota Surabaya

Metode: Jenis penelitian yaitu observasional analitik dengan menggunakan desain cross-sectional. Sampel penelitian sebesar 54 baduta dipilih menggunakan metode simple random sampling. Kuesioner Dietary Diversity Score digunakan untuk menilai keragaman pangan baduta dan food recall 24-hours untuk mengetahui frekuensi pemberian makanan. Uji statistik menggunakan chi-square.

Hasil: Hasil dari penelitian ini menunjukkan tidak adanya korelasi antara karakteristik keluarga, baduta, dan keberagaman pangan dengan kejadian stunting. Akan tetapi, terdapat korelasi antara pendapatan orang tua $(\mathrm{p}=0,006)$ dan frekuensi pemberian MP-ASI dengan kejadian stunting $(\mathrm{p}=0,028)$.

Kesimpulan: Pendapatan orang tua dan frekuensi pemberian MP-ASI berhubungan dengan stunting sedangkan, karakteristik keluarga, baduta, dan keragaman pangan tidak berhubungan dengan kejadian stunting
\end{abstract}

Kata kunci: stunting, makanan pendamping, karakteristik keluarga, keragaman pangan

\section{ABSTRACT}

Background: Nutritional problems are susceptible to occur in children under two years one of them is stunting. Stunting is a chronic nutritional problem caused by an accumulative process of inadequate nutrient intake and infectious disease. Another cause is socio-economic that can affect complementary feeding practices. The nutritional quality of food might be influenced by food diversity which can be determined by family income, employment status, and level of education.

Objectives: To analyze the association between complementary feeding practices with stunted and non-stunted children aged 6-24 months in Sidotopo, Surabaya

Methods: This research was an observational analytic with a cross-sectional research design. The Sample of this study was 54 children under two years (aged 6-24 months) obtained from a simple random sampling method. Data collection of diversity food used Dietary Diversity Score, variable of complementary feeding frequency used food recall 24-hours, and questionnaire for socio-economics data. Data were analyzed using SPSS software for windows with a chi-square test.

Results: The results showed no significant correlation between family and children characteristics and dietary diversity with an incidence of stunting. Meanwhile, a significant correlation was found between family income $(p=0.006)$ and complementary feeding frequency $(p=0.028)$ with an incidence of stunting.

Conclusions: Family income and frequency of complementary feeding related to the incidence of stunting. Family and children characteristics and dietary diversity are not related to the incidence of stunting. 
Keywords: stunting, complementary food, family characteristic, food diversity

\author{
*Koresponden: \\ aisya.cici.putri-2014@fkm.unair.ac.id \\ Aisya Cici Putri Haryati \\ ${ }^{1}$ Departemen Gizi, Fakultas Kesehatan Masyarakat, Universitas Airlangga, Kampus C Mulyorejo, 60115, \\ Surabaya, Jawa Timur, Indonesia
}

\title{
PENDAHULUAN
}

Masalah gizi seperti stunting merupakan masalah yang sering terjadi dan menjadi masalah utama pada negara berkembang (Dwi Utami et al., 2017). Masalah gizi rentan terjadi pada anak berusia dibawah dua tahun, sehingga penting untuk memanfaatkan 1000 hari pertama kehidupan anak sejak kehamilan ibu hingga usia dua tahun atau yang sering disebut golden age (Kementrian Kesehatan RI, 2015). Stunting merupakan kondisi dimana tinggi badan menurut usia anak kurang dari -2SD berdasarkan standard WHO (WHO, 2010). Dampak yang dapat diakibatkan dari stunting yaitu diantaranya gangguan perkembangan dan kecerdasan otak, pertumbuhan fisik yang tidak maksimal dan juga berisiko mengalami penyakit degeneratif di usia dewasa (Kementrian Kesehatan RI, 2016).

Anak berusia dibawah lima tahun yang mengalami stunting di Dunia sebesar 22\% dari jumlah keseluruhan balita pada tahun 2018 atau sekitar 149 juta balita menderita stunting (WHO dan Bank, 2019), angka tersebut menurun dibandingkan dengan jumlah balita stunting pada tahun 2016 yaitu sebesar 22,9\% (WHO dan Bank, 2017). Di Indonesia pada tahun 2018 masalah gizi stunting yaitu sebesar 30,8\% menurun dari 2013 yang mencapai 37,2\% (Kementerian Kesehatan RI, 2018). Meskipun terjadi penurunan, stunting masih menjadi masalah kesahatan masyarakat yang butuh segera ditangani lebih serius karena WHO menetapkan batasan masalah gizi tidak lebih dari 20\% (Aryastami, 2017). Di Jawa Timur pada tahun 2018 prevalensi masalah gizi stunting sebesar 32,8\%, lebih tinggi dibandingkan dengan prevalensi stunting di Indonesia yang sebesar 30,8\% (Kementerian Kesehatan RI, 2018). Sedangkan di Kota Surabaya prevalensi stunting pada tahun 2017 sebesar 22,8\% (Kementerian Kesehatan RI, 2018). Kelurahan Sidotopo yang terdapat di wilayah Kecamatan Semampir dipilih sebagai lokasi penelitian karena berdasarkan data Puskesmas Sidotopo terjadi peningkatan prevalensi stunting yaitu pada tahun 2017 sebesar 10\% dan pada tahun 2018 meningkat menjadi $14,3 \%$.

Stunting yang terjadi pada usia 0-2 tahun dan tetap pendek pada usia 4-6 tahun memiliki risiko untuk 27 kali untuk tetap mengalami pendek saat usia remaja (Aryastami, 2015). Terhambatnya pertumbuhan secara linier dapat terjadi karena gagalnya proses perkembangan yang diakibatkan dari kondisi kesehatan yang rendah dan kurangnya asupan nutrisi (Aridiyah et al., 2015). Faktor sosial ekonomi seperti tingkat pendidikan orangtua dan pendapatan keluarga berpengaruh terhadap terjadinya stunting akibat dari rendahnya asupan gizi secara kualitas dan kuantitas (Pehlke et al., 2016). Penelitian yang lainnya menyebutkan faktor yang menyebabkan stunting diantaranya disebabkan oleh faktor anak seperti jenis kelamin, riwayat ASI eksklusif, dan usia awal pemberian MP-ASI (Rachmi et al., 2016).

Pemberian MP-ASI harus mencukupi kebutuhan gizi anak yang sudah tidak didapatkan lagi dari ASI. Zat gizi yang perlu untuk dicukupi adalah, energi, karbohidrat, protein, lemak, dan mikronutrien sehingga perlu adanya keberagaman pangan pada MP-ASI agar terpenuhi kebutuhan gizi anak (Kathryn Dewey, 2001). Masalah stunting menarik untuk dibahas karena masih menjadi masalah kesehatan masyarakat dan banyak faktor yang mempengaruhi diantaranya adalah hubungannya dengan praktik pemberian MP-ASI pada anak usia 6-24 bulan.

\section{METODE}

Penelitian dilaksanakan pada bulan oktober hingga november tahun 2018 di Kelurahan Sidotopo, Kota Surabaya. Penelitian dilakukan dengan metode observasional analitik dengan menggunakan desain cross sectional. Populasi dalam penelitian ini adalah seluruh anak dengan usia 6 hingga 24 bulan. Jumlah sampel didapatkan dengan menggunakan rumus lemeshow (Darwati et al., 2016) yang selanjutnya didapatkan sejumlah 54 baduta yang dipilih menggunakan metode simple random sampling

Variabel terikat pada penelitian ini adalah stunting, sedangkan variabel bebasnya adalah frekuensi pemberian MP-ASI, keragaman pangan, jenis kelamin, usia dan tinggi badan baduta, pekerjaan dan pendidikan ibu, serta pendapatan keluarga tiap bulan. Data primer yang didapatkan dalam penelitian ini adalah berupa pengukuran tinggi badan menggunakan microtoise dengan ketelitian $0,1 \mathrm{~cm}$ untuk baduta yang telah dapat berdiri dengan baik, dan panjang badan menggunakan length board dengan ketelitian $0,1 \mathrm{~cm}$ bagi baduta yang belum dapat berdiri dengan baik, selain itu data primer juga didapatkan dengan menggunakan kuesioner yang meliputi karakteristik baduta seperti jenis kelamin, usia dan tinggi badan baduta. Karakteristik keluarga meliputi pekerjaan ibu, pendapatan keluarga, serta tingkat pendidikan terakhir ibu. Praktik pemberian MP-ASI yaitu 
frekuensi pemberian MP-ASI dinilai dengan menggunakan data recall asupan makanan baduta yang dilakukan sebanyak dua kali, sedangkan keberagaman makanan baduta diperoleh dengan wawancara terhadap ibu atau pengasuh dengan menggunakan instrumen Dietary Diversity Score (DDS) yang terdiri dari 7 kelompok pangan yaitu serelia dan umbi-umbian, kacang-kacangan dan biji-bijian, susu dan turunannya, daging, telur, buah dan sayur kaya vitamin A, sayuran dan buah lainnya. DDS merupakan instrumen untuk mengukur asupan makanan secara kualitatif yang dapat menggambarkan kecukupan gizi dari makanan individu. Dikatakan seorang telah makan dengan beragam apabila telah mengkonsumsi $\geq 4$ kelompok pangan dan tidak beragam jika $<4$ kelompok pangan (FAO, 2010). Data selanjutnya dianalisis menggunakan Uji chi-square untuk mengetahui hubungan antara karakteristik baduta, karakteristik keluarga dan praktik pemberian MP-ASI dengan stunting.

Penelitian ini telah mendapatkan persetujuan dari Komisi Etik Penelitian Fakultas Kesehatan Masyarakat Universitas Airlangga dengan nomor: 543/EA/KEPK/2018. Sementara persetujuan untuk mengikuti peneitian dari baduta didapatkan melalui Inform Consent yang ditandatangani oleh ibu atau pengasuh baduta.

\section{HASIL DAN PEMBAHASAN}

Tabel 1. Distribusi Karakteristik Balita dan Keluarga pada Kelompok Stunting dan Non-Stunting

\begin{tabular}{|c|c|c|c|c|c|c|c|}
\hline \multirow{2}{*}{ Variabel } & \multicolumn{2}{|c|}{ Stunting } & \multicolumn{2}{|c|}{ Non-Stunting } & \multicolumn{2}{|c|}{ Total } & \multirow{2}{*}{$\mathrm{p}$-value } \\
\hline & $\mathrm{n}$ & $\%$ & $\mathrm{n}$ & $\%$ & $\mathrm{n}$ & $\%$ & \\
\hline \multicolumn{8}{|l|}{ Usia Baduta } \\
\hline $9-12$ bulan & 3 & 33,3 & 13 & 28,9 & 16 & 29,6 & \multirow{2}{*}{0,790} \\
\hline 13-24 bulan & 6 & 66,7 & 32 & 71,1 & 38 & 70,4 & \\
\hline \multicolumn{8}{|l|}{ Jenis kelamin } \\
\hline Laki-laki & 3 & 33,3 & 20 & 44,4 & 23 & 16,7 & \multirow{2}{*}{0,538} \\
\hline Perempuan & 6 & 66,7 & 25 & 55,6 & 31 & 83,3 & \\
\hline \multicolumn{8}{|l|}{ Pendidikan Ibu } \\
\hline Tamat SD & 4 & 44,4 & 7 & 15,6 & 11 & 20,4 & \multirow{3}{*}{0,145} \\
\hline Tamat SMP & 2 & 22,2 & 15 & 33,3 & 17 & 31,5 & \\
\hline Tamat SMA & 3 & 33,3 & 23 & 51,1 & 26 & 48,1 & \\
\hline \multicolumn{8}{|l|}{ Pekerjaan Ibu } \\
\hline Tidak Bekerja & 7 & 77,8 & 35 & 77,8 & 42 & 22,2 & \multirow{2}{*}{0,100} \\
\hline Bekerja & 2 & 22,2 & 10 & 22,2 & 12 & 77,8 & \\
\hline \multicolumn{8}{|l|}{ Penghasilan Orang tua } \\
\hline $500.000-2.500 .00$ & 5 & 55,6 & 15 & 33,3 & 20 & 55,6 & \multirow{3}{*}{0,006} \\
\hline 2.500.000-3.500.00 & 1 & 11,1 & 22 & 48,9 & 23 & 24,0 & \\
\hline$>3.500 .000$ & 3 & 33,3 & 8 & 17,8 & 11 & 20,4 & \\
\hline
\end{tabular}

Pada penelitian ini karakteristik baduta meliputi usia baduta dan jenis kelamin, karakteristik orangtua meliputi pendidikan ibu, pekerjaan ibu, dan pendapatan keluarga. Hasil dari 54 baduta yang diteliti sebanyak 9 baduta mengalami stunting. Berdasarkan tabel 1, diketahui proporsi baduta terbanyak yang mengalami stunting pada usia 13-24 bulan begitu juga pada baduta yang memiliki tinggi badan yang normal terbanyak juga pada usia 13-24 bulan dengan nilai $\mathrm{p}=0,790$ yang artinya tidak ada hubungan antara usia baduta dengan kejadian stunting. Pada penelitian ini mayoritas baduta yang diteliti berjenis kelamin perempuan. Hasil uji chi-square pada penelitian ini menyatakan bahwa tidak ada hubungan yang bermakna antara jenis kelamin baduta dengan kejadiian stunting $(\mathrm{p}=0,538)$. Hasil ini sejalan dengan penelitian yang telah dilakukan sebelumnya di Bangladesh yang menunjukkan bahwa tidak terdapat perbedaan status gizi pada anak laki-laki maupun perempuan (Mohsena et al., 2010). Hal ini dikarenakan banyak faktor yang dapat mempengaruhi status gizi baduta diantaranya adalah asupan makanan yang kurang serta adanya penyakit infeksi (Setiawan et al., 2018). Selain itu, dapat juga dikarenakan pada penelitian ini mayoritas responden berjenis kelamin perempuan sehingga data homogen.

Proporsi ibu baduta yang tidak bekerja lebih besar dibandingakan dengan ibu yang bekerja. Hasil penelitian menunjukkan sebagian besar ibu merupakan ibu yang tidak bekerja atau hanya menjadi ibu rumah tangga yaitu sebesar $77,8 \%$. Penelitian yang dilakukan sebelumnya menyatakan tidak terdapat hubungan antara pekerjaan ibu dengan status gizi anak (Sukoco et al., 2015), sejalan dengan hasil uji chi-square pada penelitian ini yang menyatakan bahwa tidak ada hubungan yang signifikan antara pekerjaan ibu dengan status gizi stunting $(\mathrm{p}=0,100)$

Berdasarkan hasil penelitian, tingkat pendidikan ibu beragam namun dengan persentase tertinggi pada ibu dengan lulusan SMA yaitu sebesar 48,1\%. Uji statistik chi-square menunjukkan hasil yang tidak signifikan antara pendidikan ibu dengan kejadian stunting baduta, namun hasil penelitian menunjukkan prevalensi stunting yang lebih tinggi pada ibu tamatan SD. Penelitian sebelumnya menyebutkan bahwa semakin tinggi pendidikan ibu maka akan semakin mudah ibu untuk menerima informasi terkait asupan makanan dan tumbuh kembang anak serta mampu mempraktikannya dengan baik (Oemar dan Novita, 2015). Namun terdapat penelitian lainnya 
menyebutkan bahwa tidak terdapat hubungan yang signifikan antara pendidikan ibu dengan status gizi balita. ibu dengan pendidikan rendah juga mampu mendapatkan informasi terkait gizi anak melalui petugas kesehatan di posyandu, puskesmas, maupun di rumah sakit dengan pemberian informasi yang sederhana dan mudah untuk dipahami (Lestari, 2015).

Pendapatan orangtua di daerah sidotopo sebagian besar berada pada pendapatan rendah yaitu berkisar Rp.500.000 - Rp.2.500.000. Sebagian besar pendapatan didapatkan oleh ayah karena ibu tidak bekerja. Berdasarkan hasil uji chi-square $(\mathrm{p}=0,006)$, ditemukan adanya hubungan yang bemakna antara pendapatan orang tua dengan kejadian stunting pada baduta. Hasil ini sejalan dengan penelitian sebelumnya yang menyebutkan bahwa balita yang memiliki orang tua dengan pendapatan yang rendah dapat meningkatkan risiko 4 kali lebih besar akan mengalami gizi kurang dibanding dengan pendapatan yang cukup (Persulessy et al., 2016). Pendapatan keluarga dapat mempengaruhi daya beli pangan, karena pendapatan yang rendah dapat mengakibatkan semakin rendahnya pilihan pangan yang mampu dibeli serta akan menyebabkan penurunan kualitas dan kuantitas pangan, sehingga pemenuhan gizi bagi anak pun juga akan semakin terbatas. Pada penelitian yang dilakukan di Angola menyebutkan bahwa sosial ekonomi keluarga yang rendah merupakan faktor risiko utama yang dapat menyebabkan stunting (Kennedy et al., 2006). Kondisi sosial ekonomi berkaitan dengan kualitas dan kuantitas makanan yang dapat diberikan pada anak (Ulfani et al., 2011).

Pada tabel 2 dapat diketahui pada mayoritas baduta stunting (77,8\%) tidak mendapatkan frekuensi makan yang sesuai dengan usianya, sedangkan pada baduta tidak stunting mendapatkan frekuensi makan yang sesuai dengan usianya. Berdasaran hasil penelitian yang telah dilakukan didapatkan nilai $\mathrm{p}=0,028$ yang artinya terdapat hubungan yang signifikan antara frekuensi pemberian MP-ASI dengan kejadian stunting. Sesuai dengan penelitian sebelumnya yang menyatakan adanya hubungan yang bermakna antara frekuensi pemberian MP-ASI dengan status gizi stunting (Widyaswari, 2011). Frekuensi pemberian MP-ASI yang lebih sering membuat asupan gizi yang diterima anak akan semakin banyak dan dapat meningkatkan status gizi anak. Sejalan juga dengan penelitian yang dilakukan di Kota Palu yang menyatakan adanya hubungan antara food frequency dengan kejadian stunting (Hijr et al., 2016).

Tabel 2. Hubungan Frekuensi Pemberian MP-ASI dan Keragaman Pangan dengan Kejadian Stunting

\begin{tabular}{lccccccc} 
& \multicolumn{2}{c}{ Variabel } & \multicolumn{2}{c}{ Stunting } & \multicolumn{2}{c}{ Non-Stunting } & \multicolumn{2}{c}{ Total } & p-value \\
\cline { 2 - 6 } & $\mathrm{n}$ & $\%$ & $\mathrm{n}$ & $\%$ & $\mathrm{n}$ & $\%$ & \\
\hline Frekuensi Pemberian MP-ASI & 2 & 22,2 & 29 & 64,4 & 31 & 57,4 & 0,028 \\
Sesuai & 7 & 77,8 & 16 & 35,6 & 23 & 42,6 & \\
Tidak Sesuai & & & & & & & \\
Keberagaman Pangan & 4 & 44,4 & 25 & 55,6 & 29 & 53,7 & 0,542 \\
Sesuai & 5 & 55,6 & 20 & 44,4 & 25 & 46,3 & \\
Tidak Sesuai & & & & & &
\end{tabular}

Pada penelitian ini $57,4 \%$ baduta sudah mendapatkan frekuensi makan yang sesuai dengan usianya, meskipun masih ada yang belum sesuai yaitu sebesar $42,6 \%$. Berdasarkan hasil wawancara dengan ibu atau pengasuh dan melihat dari hasil recall makan baduta yang belum memberikan frekuensi makan sesuai dengan usia anaknya dikarenakan anak yang susah makan dan hanya suka mengemil atau mengkonsumsi susu formula. Gangguan linier pada anak disebabkan karena kualitas dan kuantitas dari MP-ASI yang tidak memadai. Apabila frekuensi makan tidak sesuai dengan usianya maka anak akan kekurangan zat gizi yang dibutuhkan oleh tubuh dan dapat mengakibatkan penyakit infeksi (Nai et al., 2014). Anak yang diberi pola makan yang dengan baik secara kualitas dan kuantitas tidak mudah untuk mengalami stunting. Pada keadaan malnutrisi, kualitas dan kuantitas makanan sangat penting dikarenakan pertumbuhan dipengaruhi oleh asupan makanan (Qu et al., 2017). Pada penelitian ini keragaman makan pada baduta dinilai dengan menggunakan instrument dietary diversity score $(D D S)$ yang berisi 7 kelompok pangan. Anak harus makan paling tidak 4 kelompok bahan pangan yang terdiri dari makanan pokok, lauk pauk, sayur dan buah (Wantina, Rahayu dan Yuliana, 2017) sehingga kebutuhan zat gizi baduta yang meliputi karbohidat, protein, lemak, mineral, dan vitamin dapat terpenuhi (Monte dan Giugliani, 2004). Keragaman makanan seharusnya sudah diperkenalkan lebih dulu sebelum berusia lima tahun dikarenakan pada setiap kelompok pangan mengandung zat gizi yang essensial yang dapat memenuhi kebutuhan nutrisi balita (Rah et al., 2010). Pada penelitian ini baduta terbanyak mengkonsumsi lebih dari 4 kelompok pangan (53,7\%). Pada tabel 2 dapat diketahui bahwa pada baduta stunting 55,6\% diantaranya tidak diberikan MP-ASI yang tidak beragam. Sementara itu, baduta tidak stunting 55,6\% diberikan MP-ASI yang beragam. Uji statistik chi-square menyebutkan nilai $p=0,79$ yang artinya tidak terdapat hubungan yang signifikan antara keragaman pangan dengan kejadian stuntin. Hasil ini sesuai dengan penelitian sebelumnya yang menyebutkan tidak adanya hubungan yang signifikan antara keberagaman pangan dengan kejadian stunting (Nurmayasanti dan Mahmudiono, 2019). Namun, hasil yang berbeda ditunjukkan pada penelitian yang dilakukan di Babakan Madang menyebutkan bahwa balita yang mengkonsumsi kurang dari 4 grup makanan berisiko untuk mengalami stunting (Trisasmita et al., 2020). Tidak adanya hubungan yang bermakna antara keragaman pangan 
dengan kejadian stunting dapat disebabkan karena pada penelitian ini penilaian keragaman pakan baduta hanya dilakukan dengan recall 2x24 jam sehingga hasil kurang menggambarkan pola makan anak secara keseluruhan.

Tabel 3. Distribusi Konsumsi Pangan Baduta pada Kelompok Stunting dan Non-Stunting

\begin{tabular}{|c|c|c|c|c|}
\hline \multirow{2}{*}{ Variabel } & \multicolumn{2}{|c|}{ Stunting } & \multicolumn{2}{|c|}{ Non-Stunting } \\
\hline & $\mathrm{n}$ & $\%$ & $\mathrm{n}$ & $\%$ \\
\hline \multicolumn{5}{|l|}{ Serelia dan Umbi-umbian } \\
\hline Nasi & 5 & 55,6 & 35 & 77,8 \\
\hline Bubur & 3 & 33,3 & 5 & 11,1 \\
\hline Mie & 0 & 0,0 & 4 & 8,9 \\
\hline Kentang & 1 & 11,1 & 3 & 6,7 \\
\hline Lontong & 0 & 0,0 & 1 & 2,2 \\
\hline Tidak konsumsi serelia & 0 & 0,0 & 0 & 0,0 \\
\hline \multicolumn{5}{|l|}{ Kacang-kacangan dan biji-bijian } \\
\hline Kacang Hijau & 0 & 0,0 & 2 & 4,4 \\
\hline Tempe & 3 & 33,3 & 13 & 28,9 \\
\hline Tahu & 1 & 11,1 & 11 & 24,5 \\
\hline Tidak konsumsi kacang-kacangan & 5 & 55,6 & 19 & 42,2 \\
\hline \multicolumn{5}{|l|}{ Susu dan turunannya } \\
\hline ASI & 0 & 0,0 & 27 & 60,0 \\
\hline Susu Formula & 7 & 77,8 & 17 & 37,8 \\
\hline Susu kental manis & 2 & 22,2 & 1 & 2,2 \\
\hline Tidak konsumsi susu & 0 & 0,0 & 0 & 0,0 \\
\hline \multicolumn{5}{|l|}{ Daging } \\
\hline Daging ayam & 0 & 0,0 & 11 & 24,4 \\
\hline Daging sapi & 0 & 0,0 & 3 & 6,6 \\
\hline Hati sapi & 1 & 11,1 & 2 & 4,4 \\
\hline Ikan & 0 & 0,0 & 3 & 6,6 \\
\hline Tiidak konsumsi daging & 8 & 88,9 & 19 & 42,2 \\
\hline \multicolumn{5}{|l|}{ Telur } \\
\hline Telur ayam & 3 & 33,3 & 12 & 26,7 \\
\hline Telur puyuh & 1 & 11,1 & 3 & 6,6 \\
\hline Tidak konsumsi telur & 5 & 55,6 & 30 & 66,7 \\
\hline \multicolumn{5}{|l|}{ Buah dan sayur kaya vitamin A } \\
\hline Wortel & 1 & 11,1 & 5 & 11,1 \\
\hline Bayam & 2 & 22,2 & 4 & 8,9 \\
\hline Kangkung & 0 & 0,0 & 2 & 4,4 \\
\hline Pepaya & 1 & 11,1 & 2 & 4,4 \\
\hline Kacang Panjang & 0 & 0,0 & 3 & 6,7 \\
\hline Tiidak konsumsi sayur dan buah vitA & 5 & 55,6 & 29 & 64,5 \\
\hline \multicolumn{5}{|l|}{ Sayuran dan Buah lainnya } \\
\hline Semangka & 1 & 11,1 & 1 & 2,2 \\
\hline Pisang & 1 & 11,1 & 2 & 4,4 \\
\hline Terong & 0 & 0,0 & 1 & 2,2 \\
\hline Buncis & 1 & 11,1 & 4 & 8,9 \\
\hline Jeruk & 0 & 0,0 & 1 & 2,2 \\
\hline Timun krai & 0 & 0,0 & 2 & 4,4 \\
\hline Labu siam & 0 & 0,0 & 2 & 4,4 \\
\hline Tidak konsumsi buah dan sayuran & 6 & 66,7 & 32 & 71,2 \\
\hline
\end{tabular}

Dapat dilihat pada tabel 3, seluruh baduta stunting maupun non-stunting mengkonsumsi kelompok pangan serelia dan umi-umbian dengan sebagian besar mengkonsumsi nasi. Pada kelompok pangan kacangkacangan sebagian besar mengkonsumsi jenis kedelai yang di olah menjadi tempe. Pada kelompok pangan susu dan turunannya, 27 baduta yang tidak diberikan susu masih mendapatkan ASI. Hampir seluruh baduta mengkonsumsi susu. Pada keluarga dengan pendapatan yang rendah terdapat baduta yang diberikan susu kental manis ataupun air gula. Pada kelompok pangan daging dapat diketahui hanya satu baduta $(11,1 \%)$ yang mengkonsumsi hati, sedangkan pada kelompok baduta non-stunting lebih dari $50 \%$ mengkonsumsi daging. Daging merupakan bahan makanan sumber protein hewani. Protein yang bersumber dari hewani merupakan protein dengan nilai biologi tinggi karena mengandung asam amino esensial lengkap yang dibutuhkan dalam proses pertumbuhan (Ilmu Gizi Teori dan Aplikasi, 2020). Sesuai dengan penelitian yang telah dilakukan 
sebelumnya yang menyebutkan bahwa terdapat hubungan antara asupan protein dengan kejadan stunting pada balita. Balita yang kekurangan protein memiliki risiko 17,5 kali mengalami stunting jika dibandingkan dengan balita yang memiliki asupan protein cukup (Sulistianingsih dan Yanti, 2016). Protein memiliki pengaruh yang sangat penting terhadap pertumbuhan balita, secara umum fungsi protein untuk pertumbuhan, pembentukan komponen struktural, dan pembentukan antibody (Ilmu Gizi Teori dan Aplikasi, 2020).

Stunting disebabkan oleh efek akumalatif dari rendahnya asupan zat gizi makro dan mikro selama periode yang lama ataupun hasil dari infeksi kronis (Umeta et al., 2003). Skor keragaman makanan menggambarkan kualitas MP-ASI (Moursi et al., 2008). Namun Keragaman konsumsi pangan dapat dipengaruhi oleh pendapatan rumah tangga, dimana pendapatan yang tinggi dapat menyebabkan tingginya keragaman pangan (Cahyani, 2008). Pada penelitian ini berdasarkan karakteristik keluarga dapat diketahui pendapatan keluarga yang cukup rendah, maka kesempatan untuk mengkonsumsi makanan yang beragam juga rendah. Sedangkan asupan makan yang beragam dapat meningkatkan asupan energi dan zat gizi mikro. Dietary Diversity Score sangat erat kaitannya dengan kualitas dan kecukupan gizi pada MP-ASI anak, dikarenakan setiap kali makan anak akan mendapatkan zat gizi yang berbeda dan beragam (Udoh dan Amodu, 2016).

\section{KESIMPULAN}

Hasil penelitian menunjukkan bahwa terdapat hubungan bermakna antara frekuensi pemeberian MPASI dengan stunting, namun tidak ada hubungan antara pendidikan dan pekerjaan ibu, karakteristik baduta, dan juga keragaman pangan dengan stunting. Peneliti merekomendasikan pada peneliti selanjutnya untuk mencari faktor-faktor lain yang dapat mempengaruhi kejadian stunting seperti riwayat penyakit infeksi dan juga tingkat higiene sanitasi.

\section{ACKNOWLEDGEMENT}

Ucapan terima kasih kepada Dinas Kesehatan Kota Surabaya yang telah mengizinkan penelitian ini dilakukan di Puskemas Sidotopo yang berada di Kecamatan Semampir

\section{REFERENSI}

Aridiyah, Farah Okky, Rohmawati, Ninna, Ririanty, M. (2015) 'Faktor-faktor yang Mempengaruhi Kejadian Stunting pada Anak Balita di Wilayah Pedesaan dan Perkotaan', e-Jurnal Pustaka Kesehatan, 3(1), pp. 163-170.

Aryastami, N. K. (2015) 'Pertumbuhan usia dini menentukan pertumbuhan hingga usia pra- pubertas ( studi longitudinal IFLS 1993-1997-2000 = Early child s growth has appointed growth at pre puberty longitudinal study of IFLS 1993-1997-2000)'.

Aryastami, N. K. (2017) 'Kajian Kebijakan dan Penanggulangan Masalah Gizi Stunting di Indonesia', Buletin Penelitian Kesehatan, 45(4), pp. 233-240. doi: 10.22435/bpk.v45i4.7465.233-240.

Atin Nurmayasanti dan Trias Mahmudiono (2019) 'Status Sosial Ekonomi dan Keragaman Pangan Pada Balita Stunting dan Non-Stunting Usia 24-59 Bulan di Wilayah Kerja Puskesmas Wilangan Kabupaten Nganjuk ', Amerta Nutrition, 3(2), pp. 114-121. doi: 10.2473/amnt.v3i2.2019.114-121.

Cahyani, G. I. (2008) 'Analisis Faktor Sosial Ekonomi Keluarga terhadap Keanekaragaman Konsumsi Pangan Berbasis Agribisnis Di Kabupaten Banyumas', pp. 1-59.

Darwati, D. et al. (2016) 'Pengaruh Intervensi Konseling Feeding Rules dan Stimulasi Terhadap Status Gizi dan Perkembangan Anak di Posyandu Kabupaten Jayapura', Sari Pediatri, 15(6), p. 377. doi: 10.14238/sp15.6.2014.377-84.

Dwi Utami, A., Lanti, Y. dan Dewi, R. (2017) 'The Effect of Nutrient Intake and Socioeconomic Factor toward Stunting Incidence among Primary School Students in Surakarta', Journal of Epidemiologi and Publich Health, 2(1), pp. 1-10.

Food and Agriculture Organization (2010) Guidelines for measuring household and individual dietary diversity, Fao.

Hijra, H., Fatimah-Muis, S. dan Kartasurya, M. I. (2016) 'Inappropriate complementary feeding practice increases risk of stunting in children aged 12-24 months', Universa Medicina, 35(3), p. 146. doi: 10.18051/univmed.2016.v35.146-155.

Ilmu Gizi Teori dan Aplikasi (2020).

Kathryn Dewey (2001) 'Guiding Principles for Complementary Feeding of The Breasfead'. PAN AMERICA HEALTH ORGANIZATION.

Kementerian Kesehatan RI (2018) 'Buku saku pemantauan status gizi', Buku saku pemantauan status gizi tahun 2017, pp. 7-11.

Kementerian Kesehatan RI Badan Penelitian dan Pengembangan (2018) Hasil Utama Riset Kesehatan Dasar, 
Kementrian Kesehatan Republik Indonesia.

Kementrian Kesehatan RI (2015) 'Jurnal No. 3 kemenkes, 2015.pdf'.

Kementrian Kesehatan RI (2016) 'Situasi Balita Pendek'.

Kennedy, G. et al. (2006) 'Does living in an urban environment confer advantages for childhood nutritional status? Analysis of disparities in nutritional status by wealth and residence in Angola, Central African Republic and Senegal', Public Health Nutrition, 9(2), pp. 187-193. doi: 10.1079/phn2005835.

Lestari, N. D. (2015) 'Analisis Determinan Status Gizi Balita di Yogyakarta', Mutiara Medika: Jurnal Kedokteran dan Kesehatan, 15(1), pp. 21-27.

Mohsena, M., Mascie-Taylor, C. N. dan Goto, R. (2010) 'Association between socio-economic status and childhood undernutrition in Bangladesh; A comparison of possession score and poverty index', Public Health Nutrition, 13(10), pp. 1498-1504. doi: 10.1017/S1368980010001758.

Monte, C. M. G. dan Giugliani, E. R. J. (2004) 'Recommendations for the complementary feeding of the breastfed child', Jornal de Pediatria, 80(8), pp. 131-141. doi: 10.2223/jped.1245.

Moursi, M. M. et al. (2008) 'Dietary diversity is a good predictor of the micronutrient density of the diet of 6- to 23-month-old children in Madagascar', Journal of Nutrition, 138(12), pp. 2448-2453. doi: $10.3945 /$ jn.108.093971.

Nai et al (2014) 'Praktik pemberian makanan pendamping asi (mp-asi) sebagai faktor risiko kejadian', Tesis, 2(1), pp. 126-139. doi: 10.1039/c0an00880j.

Oemar, R. dan Novita, A. (2015) 'Pola Asuh Dalam Kesehatan Anak Pada Ibu Buruh Pabrik', Jurnal Kesehatan Masyarakat, 11(1), p. 112. doi: 10.15294/kemas.v11i1.3543.

Pehlke, E. L. et al. (2016) 'Guatemalan school food environment: Impact on schoolchildren's risk of both undernutrition and overweight/obesity', Health Promotion International, 31(3), pp. 542-550. doi: 10.1093/heapro/dav011.

Persulessy, V., Mursyid, A. dan Wijanarka, A. (2016) 'Income level and diet pattern had correlation with nutritional status of underfive in fisherman area of North Jayapura District Jayapura Municipality', Jurnal Gizi dan Dietetik Indonesia (Indonesian Journal of Nutrition and Dietetics), 1(3), p. 143. doi: 10.21927/ijnd.2013.1(3).143-150.

Qu, P. et al. (2017) 'Association between the Infant and child feeding Index (ICFI) and nutritional status of 6- to 35-month-old children in rural western China', PLoS ONE, 12(2), pp. 1-14. doi: 10.1371/journal.pone.0171984.

Rachmi, C. N. et al. (2016) 'Stunting, underweight and overweight in children aged 2.0-4.9 years in Indonesia: Prevalence trends and associated risk factors', PLoS ONE, 11(5), pp. 1-17. doi: 10.1371/journal.pone.0154756.

Rah, J. H. et al. (2010) 'Low dietary diversity is a predictor of child stunting in rural Bangladesh', European Journal of Clinical Nutrition. Nature Publishing Group, 64(12), pp. 1393-1398. doi: 10.1038/ejen.2010.171.

Setiawan, E., Machmud, R. dan Masrul, M. (2018) 'Faktor-Faktor yang Berhubungan dengan Kejadian Stunting pada Anak Usia 24-59 Bulan di Wilayah Kerja Puskesmas Andalas Kecamatan Padang Timur Kota Padang Tahun 2018', Jurnal Kesehatan Andalas, 7(2), p. 275. doi: 10.25077/jka.v7i2.813.

Sukoco, noor edi widya, Pambudi, J. dan Herawati, maria holly (2015) 'Hubungan Status Gizi Anak Balita Dengan Orang Tua Bekerja', Buletin Penelitian Sistem Kesehatan, 18(4), pp. 387-397.

Sulistianingsih, A. dan Yanti, D. A. M. (2016) 'Kurangnya Asupan Makan Sebagai Penyebab Kejadian Balita Pendek ( Stunting )', Jurnal Dunia Kesehatan, 5(1), pp. 71-75.

Trisasmita, L. et al. (2020) 'Identification of dietary diversity associated with stunting in Indonesia', Malaysian Journal of Nutrition, 26(1), pp. 85-92. doi: 10.31246/MJN-2019-0128.

Udoh, E. E. dan Amodu, O. K. (2016) 'Complementary feeding practices among mothers and nutritional status of infants in Akpabuyo Area, Cross River State Nigeria', SpringerPlus. Springer International Publishing, 5(1). doi: 10.1186/s40064-016-3751-7.

Ulfani., Dian Hani, Drajat Martianto, Y. F. B. (2011) 'FAKTOR-FAKTOR SOSIAL EKONOMI DAN KESEHATAN MASYARAKAT KAITANNYA DENGAN MASALAH GIZI UNDERWEIGHT, STUNTED, DAN WASTED DI INDONESIA: PENDEKATAN EKOLOGI GIZI', Jurnal Gizi dan Pangan, 6(1), pp. 59-65.

Umeta, M. et al. (2003) 'Factors associated with stunting in infants aged 5-11 months in the Dodota-Sire District, Rural Ethiopia', Journal of Nutrition, 133(4), pp. 1064-1069. doi: 10.1093/jn/133.4.1064.

Wantina, M., Rahayu, L. S. dan Yuliana, I. (2017) 'Keragaman konsumsi pangan sebagai faktor risiko stunting pada balita usia 6-24 bulan', Journal UHAMKA, 2(2), pp. 89-96.

WHO (2010) 'Interpretation Guide'.

WHO dan Bank, W. (2017) 'Levels and trends in child malnutrition'.

WHO dan Bank, W. (2019) 'Levels and trends in child malnutrition'.

Widyasari, R., Fakultas Kedokteran, Universitas Sebelas Maret (2011) 'perpustakaan . uns . ac . id'. 